\section{Commentary: Is acute kidney injury after cardiac surgery the canary in the mineshaft?}

\author{
Robert S. Kramer, MD, FACS
}

In their manuscript, "Stage 1 Acute Kidney Injury is Independently Associated with Infection Following Cardiac Surgery," Griffin and colleagues ${ }^{1}$ showed in a retrospective analysis of 1555 patients that stage 1 acute kidney injury (AKI) by the Kidney Disease Improving Global Outcomes criteria is associated with an increased incidence of infection as well as increased intensive care unit (ICU) and hospital length of stay (LOS). Griffin and colleagues separated patients with stage $1 \mathrm{AKI}$ from the more severe patients with stage 2 and $3 \mathrm{AKI}$ and have shown it to be clearly associated with infection and prolonged ICU LOS. The oftencasual attitude regarding small "bumps" in creatinine by cardiac surgery providers is concerning in the light of this and other studies. Griffin and colleagues showed that the aggregate rate of infection in the stage 1 AKI group was over twice the rate of the group with no AKI. Infections included deep and superficial wound infections, cellulitis, positive blood or urine cultures, and pneumonia. Whether AKI itself drives these poor outcomes or is a signal (like the canary in the mine shaft) is not yet known. The authors hypothesize interesting mechanisms, such as immunoparalysis, an acquired immunodeficiency, due to derangements in the plasma metabolome. The metabalome is made up of thousands of metabolites that have been identified, and derangements of the metabolome effecting short- and long-term health does not take much imagination. These derangements, signaled by AKI, have long-term implications resulting in a less-favorable survival curve for patients with AKI. For example, in Brown and colleagues, ${ }^{2}$ the duration of AKI after cardiac surgery impacted long-term survival,

\footnotetext{
From the Division of Cardiothoracic Surgery, Maine Medical Center Cardiovascular Institute, Portland, Maine; and Tufts University School of Medicine, Boston, Mass. Disclosures: Author has nothing to disclose with regard to commercial support.

Received for publication Nov 22, 2019; revisions received Nov 22, 2019; accepted for publication Nov 25, 2019; available ahead of print Dec 12, 2019.

Address for reprints: Robert S. Kramer, MD, FACS, Maine Medical Center Cardiovascular Institute, 22 Bramhall St, Portland, ME 04102 (E-mail: kramer@mmc org).

J Thorac Cardiovasc Surg 2021;161:1356-7

0022-5223/\$36.00

Copyright (c) 2019 by The American Association for Thoracic Surgery

https://doi.org/10.1016/j.jtcvs.2019.11.104
}

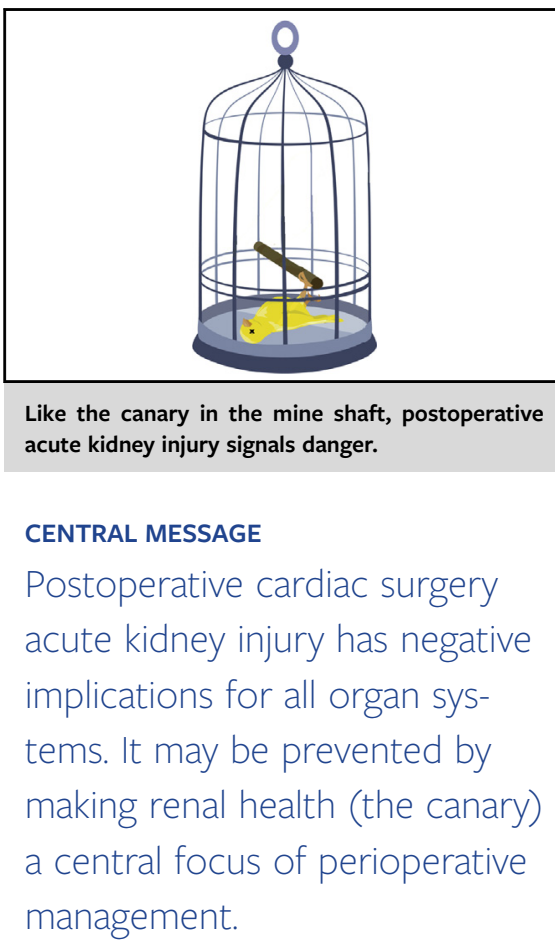

especially (and dramatically) in those patients in whom the serum creatinine did not return to baseline by the time of discharge.

Renal tubular cell health (the canary) appears to be a signal for the health of other organ systems, including the immune system. Making renal status a central focus of perioperative management means using strategies such as adequate oxygen delivery during cardiopulmonary bypass, holding angiotensin-converting enzyme inhibitors and angiotensin receptor blockers preoperatively, glucose and blood management, avoidance of contrast and other nephrotoxins, and goal-directed fluid management. In addition, urinary biomarkers (tissue inhibitor of metalloproteinases2 and insulin like growth factor-binding protein 7) are recommended for early identification of patients at risk and to guide intervention strategies to reduce AKI. Using these biomarkers to detect renal "stress" may have the potential for AKI prevention as outlined in Engelman and colleagues $^{3}$ in their article "Guidelines for Perioperative Care in Cardiac Surgery Enhanced Recovery After Surgery Society Recommendations."

How much more clarity do we need? Griffin and colleagues are not the first to send the message that AKI is a signal that we need to do something different upstream from the renal injury. Odds ratios well over 2.0 for both prolonged ICU LOS and postoperative infection should get the 
attention of all of us to take advantage of the signal we are getting from our patients' kidneys.

\section{References}

1. Griffin BR, Teixeira PJ, Ambruso S, Bronsert M, Pal JD, Cleveland JC, et al. Stage 1 acute kidney injury is independently associated with infection following cardiac surgery. J Thorac Cardiovasc Surg. 2021; 161:1346-55.e3.

2. Brown JR, Kramer RS, Coca SG, Parikh CR. Duration of acute kidney injury impacts long-term survival following cardiac surgery. Ann Thorac Surg. 2010; 90:1142-9.

3. Engelman DT, Ali WB, Williams JB, Perrault LP, Reddy VS, Arora RC, et al. Guidelines for perioperative care in cardiac surgery enhanced recovery after surgery society recommendations. JAMA Surg. 2019;154:755-66. 